\title{
Mercury-Based Mining in Yanomami Indigenous Lands and Accountabilities
}

\author{
Alan Robson Alexandrino Ramos \\ Keyty Almeida de Oliveira \\ Francilene dos Santos Rodrigues
}

${ }^{I}$ Federal University of Roraima, Boa Vista, RR, Brasil.

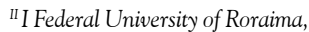
Boa Vista, RR, Brasil.

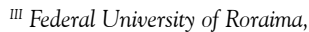
Boa Vista, RR, Brasil.

\begin{abstract}
Mercury-based gold exploitation in Amazonian indigenous lands is illegal and leads to socio-environmental impacts. Yanomami people living near mining areas in Uraricoera River are exposed to contamination by mercury, which is a metal with bioaccumulation properties. The aims of the current study are to analyze the interdisciplinary nature of mercury-based placer mining carried out in Yanomami Indigenous Land, Roraima State, as well as to evaluate State agencies' responses to this phenomenon. Based on bibliographical and documentary survey of qualitative approach, which involved Yanomami's accounts, as well as police, administrative and judicial procedures implemented from 2013 to 2017, it was possible perceiving intense use of mercury in, and damages caused by, this illicit activity, as well as insufficient state action. There are divergences between protection and responsibilities described in the Brazilian legal system and the herein investigated illegal phenomenon, which violates indigenous rights, as well as scientific and ethical imperatives that can lead to the end of the world and of the Yanomami people.
\end{abstract}

Keywords: Placer Mining, Mercury; Environment, Indigenous Lands.

São Paulo. Vol. 23, 2020

Original Article

DOI: http://dx.doi.org/10.1590/1809-4422asoc20180326r2vu2020L5AO 


\section{Introduction}

A Mining activity in the Amazon region necessarily implies landscape and nature transformation processes, as well as a series of social issues. Social conflicts resulting from the invasion of indigenous lands, and from its environmental impacts, are evident. Among them, one finds deforestation, silting and contamination of rivers, wild animals and humans with mercury.

The "gold rush" in the Brazilian Amazon region started in the mid-1980s and exposed native populations to mercury (BERZAS NEVADO et al., 2010). Artisanal mining accounts for $37 \%$ of the global anthropogenic mercury emission (GIBB; O'LEARY, 2014). Information about the amount of mercury released into the Amazon environment is controversial, although estimates show that this metal is used at 1: 1 scale. Based on unofficial data, the amount of gold extracted in the 1980s ranged from 1,000 to 2,000 tons, which allows inferring that the same amount of mercury was used in the extraction process (BRABO et al., 1999).

Amazon soils present the highest natural mercury concentrations in the world (WASSERMAN JC; HACON; WASSERMAN MA, 2003). Deforestation and mining activities expose soils to erosion and carry mercury into aquatic environments, where it is methylated by different microorganisms and enters the trophic network (GUIMARÃES et al., 2000). Methyl-mercury accumulates in fish, which are the major vehicle of organic mercury transmission to humans (MAHAFFEY, 2004).

Tropical populations living close to mining areas present the highest weekly mercury intake among all vulnerable populations worldwide (WHO, 2008). Fish is the main source of protein for indigenous populations (BARBOSA et al., 1995), a fact that raises concern about the impacts of mercury on native populations living in developed and developing countries (WHEATLEY B; WHEATLEY MA, 2000).

The area of Uraricoera River is located in Northwestern Roraima State, Brazilian Amazon region. It lies within the Yanomami Indigenous Territory, which was delimited by the Brazilian government in 1992 (BRASIL, 1992a).

Recent studies (FIOCRUZ, 2016; VEGA et al., 2018) have confirmed that indigenous communities living near facer mining activities carried out in Uraricoera River have shown worrisome levels of contamination with mercury - which is a toxic metal with bioaccumulation properties - mainly in the form of methylmercury, which leads to severe and permanent damages to human health (LARINI, 1997; GIBB; O’LEARY, 2014).

In July 2017, Brazil has signed the Minamata Convention on Mercury (BRASIL, 2018), which aims at controlling the use of mercury to help protecting human health and the environment. This international standard must be understood in line with international human rights laws, mainly with respect to protecting indigenous minorities, historical and cultural aspects, and the universality of human rights also addressed in the 1988 Federal Constitution.

Brazilian government has enacted the International Labor Organization (ILO) Convention n. 169 - through decree n. 5051, from April 19th, 2004 - to adapt itself to 
changes taking place in indigenous peoples' conditions worldwide. The convention has acknowledged indigenous peoples' interest in taking control of their institutions, lifestyle, economic development, as well as in strengthening their identities; thus, the State must provide means to enable this process. Article 15 of the aforementioned decree guarantees indigenous peoples the right to natural resources available in their lands and states; the State must guarantee the participation in the use, management and conservation of these resources. Although the Brazilian law states that ores belong to the Federal Government, the aforementioned article provides that, in case of interest in using it, there must be free, prior and informed consultation with indigenous peoples to determine whether their interests will be harmed and to assure that they will receive equitable compensation for any damage caused by exploration activities. Article 18 also states that sanctions must be applied against the unauthorized invasion of indigenous peoples' lands and against any unauthorized use of these lands by non-indigenous persons (BRASIL, 2004).

Similarly, the United Nations Declaration on indigenous peoples' rights (UN, 2008) reiterated their right to control any event capable of affecting their territory and resources, to strengthen their institutions, cultures and traditions, and to develop based on their aspirations and needs. According to Article 8, States must establish effective mechanisms to prevent and remedy actions or consequences capable of subtracting indigenous resources. Article 29 addresses indigenous peoples' right to conserve and protect the environment, as well as the productive capacity of their territories and resources. It also holds the State accountable for establishing and implementing assistance programs aimed at assuring indigenous peoples' conservation and protection. The State is also responsible for taking effective measures to prevent hazardous materials from being stored or discarded in indigenous lands or territories without their consent. In addition, there must be fair and equitable division of activities in case of mineral or water exploitation; measures must be taken to mitigate harmful environmental, economic, social, cultural and spiritual impacts deriving from such activities.

Despite state accountabilities and the acknowledged vulnerability of indigenous populations, the Yanomami people have been continuously exposed to the effects of mercury for at least three decades (VEGA, 2018). Studies have reported high contamination levels in communities living in Roraima State (CASTRO; ALBERT; PFEIFFER, 1991; SING et al., 2003; VEGA, 2018), but little is known about the direct clinical effects of this contamination on the health and well-being of these populations. Given the uninterrupted artisanal gold mining activity in the aforementioned region, the aims of the present study were to carry out an interdisciplinary analysis of mercury use in mining sites at the Yanomami Indigenous Land, Roraima State, Brazilian Amazon region, as well as to assess State agencies' responses to this phenomenon.

\section{Materials and Methods}

Interdisciplinary analysis of mercury use in mining sites at the Yanomami Indigenous Land, Roraima State, was carried out based on a bibliographic, documentary and participatory survey of qualitative approach. Such approach encompassed data about 
State bodies' performance and the testimony of miners in legal proceedings to help better understanding the origin of the mercury; as well as aspects such as mercury uses in gold mining; its impact on indigenous health and on the environment; as well as the analysis of Brazilian State agencies' responses to the phenomenon based on the legal and ethical accountability perspective.

The herein adopted empirical research sources lied on Police (Federal Police) and managerial procedures (Brazilian Institute of the Environment and Renewable Natural Resources, National Indian Foundation and National Mining Agency), as well as on legal proceedings (Federal Justice) addressing mercury seizures carried out in Roraima State, far North Brazil, from 2013 to 2017. The research also relied on authors' participant observation; on bibliographic research comprising scientific articles, books and news published in newspapers; and on the analysis of documents addressing the phenomenon. Indigenous leader Davi Kopenawa Yanomami's perception about mercury use-related consequences was taken as element of analysis.

\section{Mercury use in Gold Extraction Processes Taking Place in Mining Sites at Yanomami Indigenous Land and State's Performance}

The Yanomami Indigenous Land, which was validated by a 1992 decree (BRASIL, 1992), is located in far North Brazil, in the region covering Western Roraima State and Northern Amazon State, Legal Amazon. In 2018, a Yanomami shaman pointed out the existence of five thousand gold prospectors working in the region (FOLHA WEB, 2018); his statement was corroborated by an official document issued by the National Indian Foundation (FUNAI - Fundação Nacional do Índio) in December 2016, which highlighted the presence of the very same five thousand gold prospectors in the region (FUNDAÇÃO NACIONAL DO ÍNDIO, 2016), as well as by the case study that addressed the activity of eight hundred prospectors caught by the Brazilian Army (RAMOS; RODRIGUES, 2018) in a single mining point nestled in more than nine million hectares belonging to that indigenous land. Prospectors are "all workers involved in mineral substance-extraction activities" (RODRIGUES, 2017, p. 29).

Gold is the "most famous mineral resource in the history of mankind" (FEIGELSON, 2012, p. 247); however, according to the Yanomami people "it is nothing but shiny dust in the mud" (KOPENAWA; ALBERT, 2015, p. 344). Gold is found in its native state, rather than combined with other elements on the planet (PRESS et al., 2013); besides, it is extremely rare in nature and has high market value. It is a commodity whose price was $\mathrm{R} \$ 242.33$ (per gram) on March 22nd, 2020 (GOLDPRICE, 2020) and whose exploitation finds locational rigidness. It means that gold mining is only economically viable in specific places on the planet where its extraction is likely to happen through processes comprising gold ore separation procedures based on handling large amounts of ore with no economic value.

Uraricoera River (Northern Yanomami Indigenous Land) can be considered a placer, i.e., a gold concentration point "due to the selection of river currents" (PRESS et al., 2013, p. 82). This metal is found in there due to its origin in rocks that 
undergo weathering processes and form sediment grains, which are selected based on their weight when water flow currents pass over them. Since heavy minerals are deposited by currents faster than lighter minerals, such as quartz and feldspar, they tend to accumulate in riverbeds and sandbars. (PRESS et al., 2013, p. 87).

Mercury is a neurotoxic chemical agent (LARINI, 1997) capable of disrupting organic balance, crossing human blood-brain and blood-plasma barriers and of causing severe changes in human body's homeostasis. It is used to extract gold from other ores due to its ability to aggregate to gold; however, the process of separating mercury from gold lies on "heating it in a can until mercury vaporizes in open air, which features aggression to the environment and to prospectors' health"(SOUZA; LINS, 1989, p. 9), since mercury liquefies and evaporates at low temperatures.

Approximately 20\% of mercury used in gold extraction processes is directly dumped into rivers, whereas the remaining $80 \%$ evaporates into the atmosphere during amalgamation and enters the food chain due to metal precipitation in crops or after methylation in animals and plants consumed by indigenous individuals (BARBOSA; DÓREA, 1998).

Individuals' exposure to mercury vapors, which often happens when this metal is used by prospectors to manipulate amalgam in order to find gold, leads to its "absorption through the pulmonary route and, to a lesser extent, through the dermal route" (LARINI, 1997, p. 129). Individuals affected by such exposure often present neurological symptoms, neuropsychic disorders, vomiting and diarrhea, changes in personality and temper, anxiety, loss of ability to concentrate, depression, irritability, anorexia, weight loss, insomnia, onset of facial tremors that can extend towards the upper and lower limbs, and kidney disorders. Individuals undergoing acute mercury poisoning may die within one to five days (SOUZA; LINS, 1989; LARINI, 1997; GIBB; O’LEARY, 2014;). Mercury manipulation takes place in barges and on the banks of Uraricoera River; this activity damages the already polluted water consumed by the Yanomami (LIMA; BETHONICO; VITAL, 2018).

Cooperative Republic of Guyana, which signed the Minamata Convention on Mercury in October 2013 and ratified it in September 2014 (MINAMATA CONVENTION ON MERCURY, 2018), shares borders with Brazilian states of Roraima and Pará. This border is pointed out by gold prospectors as the main point of illicit mercury introduction in the country - to be used the Yanomami mining -, mainly through the land crossing over Tacutu Bridge, which connects Lethem County (in Guyana) to Bonfim County (in Brazil). Prospectors claim that mercury is essential for gold extraction processes.

Brazilian websites such as http://www.mercadolivre.com.br and http://www.olx. com.br enable the free sale of metallic mercury or quicksilver. The price announced on September 24th, 2019 was approximately R $\$ 1.00$ per gram of mercury. Sellers addressed likely buyers' doubts in a public way and announced that they had one hundred and fifty kilos of mercury available for sale, which would be promptly delivered at buyers' homes through postal service, upon payment by credit card. Four kilograms of mercury were purchased on September 24th, 2019 to be delivered in Boa Vista County, Roraima State. Sellers have also mentioned the likelihood of using mercury for gold amalgamation pur- 
poses, as a way of promoting the product.

Gold mining is "extremely aggressive to dormant nature and represents one of the most perverse industrial branches at environmental perspective" (MILARÉ, 2004, p. 325). This activity can lead to immeasurable environmental impacts if it takes place in forest areas of difficult access and without state control, in an illegal and criminal manner. According to Yanomami individuals, prospectors "wash the gold dust by mixing it with what they call 'azougue' in order to obtain gold. Other white people call it mercury" (KOPENAWA; ALBERT, 2015, p. 336).

The Amazon region faces gold mining activity "of the hydraulic dismantling type on alluvial deposits, but it is also done through barges and dredges working in riverbeds" (WANDERLEY, 2015, p. 100). This phenomenon is seen in Uraricoera River, in the Indigenous Yanomami Land.

According to article 20, IX of the Federal Constitution, the extracted gold is legally owned by the Brazilian Federal Government (BRASIL, 1988). The National Congress did not authorize gold extraction activities to be implemented in the Yanomami Indigenous Land or in any other Brazilian indigenous land. Likewise, the National Mining Agency did not authorize gold extraction activities to be implemented in Roraima State, far North Brazil. Roraima State does not stand out in mineral production; it was the State collecting the lowest Financial Compensation for Mineral Exploration tax in 2016 - only R $\$ 874.00$ (BRASIL, 2017a). The whole gold mining activity taking place in Roraima State in illegal.

There has been substantial increase in gold market price in the 21 st century (WANDERLEY, 2015), a fact that has intensified the illegal activity of prospectors in the Yanomami Indigenous Land. Yanomami Indians are directly affected by the harmful consequences of illegal gold mining (FIOCRUZ, 2016; MACHADO, 2016; MILARÉ, 2004), since the rich-indigenous worldview (VIVEIROS DE CASTRO, 2015) is not taken into consideration in the preventive, repressive and punitive state actions against this illegal activity.

The Brazilian Institute of the Environment and Renewable Natural Resources (IBAMA - Instituto Brasileiro do Meio Ambiente e dos Recursos Naturais Renováveis) has state supervisory powers over the import, production, sale and use of mercury in Brazil, under the terms of Law n. 6.938/81 (BRASIL, 1981) and Decree n. 97.634 from April 10th, 1989 (BRASIL, 1989), whose Article 5 determines that "in case of quicksilver sales, be them wholesale or retail operations, the respective "Metallic Mercury Operation Document will be sent to the Brazilian Institute for the Environment and Renewable Natural Resources" (BRASIL, 1989). Therefore, IBAMA's preventive inspection actions would be essential to combat the illegal use of mercury in mining activities taking place in indigenous lands.

Data on mercury seizures carried out by IBAMA in Roraima State, from 2013 to 2017, were provided by e-mail, after request based on the Access to Information Law. They have evidenced the poor performance of this Brazilian state agency, as shown in Table 1. 
Table 1 - Mercury seizures carried out by IBAMA in Roraima State, from 2013 to 2017.

\begin{tabular}{|l|l|l|} 
Year & Amount & Observation \\
\hline 2013 & 0 & No record of seizures carried out by IBAMA. \\
\hline 2014 & 0 & No record of seizures carried out by IBAMA. \\
\hline 2015 & 0 & No record of seizures carried out by IBAMA. \\
\hline 2016 & 0 & No record of seizures carried out by IBAMA. \\
\hline 2017 & $886 \mathrm{~g}$ & $\begin{array}{l}\text { Seizure and Deposit Form - TAD n. 756530/E } \\
(2224967), \text { administrative process 02025101108 / } \\
2017-79 .\end{array}$ \\
\hline
\end{tabular}

Source: IBAMA - December 1st, 2018.

According to IBAMA, "there are approximately $30 \mathrm{~kg}$ (thirty kilograms) of metallic mercury in the IBAMA-RR deposit, and approximately $19 \mathrm{~kg}$ (nineteen kilograms) were sent to IBAMA by the Federal Highway Police (PRF - Polícia Rodoviária Federal). In total, 886 grams of it were seized through TAD 756530 / E, and the rest of it was already at IBAMA Superintendence in Roraima State, before 2013*”.

The National Mining Agency (ANM - Agência Nacional de Mineração) was launched through Law n. 13.575 / 2017 (BRAZIL, 2017b), after the extinction of the National Department of Mineral Production. It has the attributions of "establishing norms and standards for mineral resource use" and of "inspecting mining activities and applying sanctions" (idem). The following data on mercury seizures resulting from inspections carried out by the National Mining Agency in Roraima State, from 2013 to 2017 - mostly due to police action and subsequent referral to the agency - were obtained by email, based on the Access to Information Law:

Table 2 - Mercury seizures carried out by the National Mining Agency from 2013 to 2017.

\begin{tabular}{|l|l|l|} 
Year & Amount & Observation \\
\hline 2013 & $572,05 \mathrm{~g}$ & Two seizures carried out by the police - 5 packs. \\
\hline 2014 & $8.193,98 \mathrm{~g}$ & Five seizures carried out by the police - 9 packs. \\
\hline 2015 & - & No record of seizures at the National Mining Agency. \\
\hline 2016 & $36.000 \mathrm{~g}$ & $\begin{array}{l}\text { One seizure carried out by the federal highway police. 1 pack (cylin- } \\
\text { der). }\end{array}$ \\
\hline 2017 & - & No record of seizures at the National Mining Agency. \\
\hline
\end{tabular}

Source: ANM - December 1st, 2018. 
Data on seizures carried out by the Federal Police - National Judicial Police, including seizures resulting from proactive policing and presented to the Federal Police in Roraima State, were extracted through the analysis of official documents associated with criminal proceedings of public access in the Federal Court in Roraima State. These documents derived from investigations carried out by the Federal Police and confirmed the small number of seizures carried out by State preventive and repressive agencies.

Table 3 - Mercury seizures carried out by the Federal Police from 2013 to 2017. Containers described in amounts followed by * did not indicate the seized weight.

\begin{tabular}{|c|c|c|c|}
\hline Year & Date & Amount & Observation \\
\hline \multirow{4}{*}{2013} & 03/24th & $\begin{array}{l}2 \text { contai- } \\
\text { ners* }\end{array}$ & $\begin{array}{l}\text { Federal Police and Brazilian Army. Eleven individuals } \\
\text { were arrested in possession of mercury used for gold mi- } \\
\text { ning activity in Uraricoera River. }\end{array}$ \\
\hline & 04/07th & $72.5 \mathrm{~g}$ & $\begin{array}{l}\text { Four bottles. Eight individuals, six of them belonging to } \\
\text { the Yanomami ethnic group, were arrested for gold mining } \\
\text { activity in Uraricoera River, Maracá Ecological Station. }\end{array}$ \\
\hline & 05/06th & $500 \mathrm{~g}$ & $\begin{array}{l}\text { Plastic packaging with mercury. Three individuals were } \\
\text { arrested in Couto Magalhães River, Yanomami Indigenous } \\
\text { Land. }\end{array}$ \\
\hline & 07/24th & $34,500 \mathrm{~g}$ & $\begin{array}{l}\text { Cylinder imported from Guyana. One individuals was } \\
\text { arrested for transporting by truck on a federal highway. }\end{array}$ \\
\hline \multirow{5}{*}{2014} & $03 / 12$ th & $700 \mathrm{~g}$ & $\begin{array}{l}\text { Military police. Seizure of mercury, weapon, ammunition } \\
\text { and precision scales. Gold mining in Paapiu, Alto Alegre } \\
\text { County - RR. One individual, who had fled at the time of } \\
\text { the approach, was arrested. }\end{array}$ \\
\hline & 06/17th & $\begin{array}{l}1 \text { small plas- } \\
\text { tic container } \\
*\end{array}$ & $\begin{array}{l}\text { ICMBio, IBAMA and Polícia Militar. Seizure of mercury, } \\
\text { gold and meat of wild animals at Cachoeira Barba de } \\
\text { Noé (Noah's Beard Waterfall), on the margins of Maracá } \\
\text { Island. Seven individuals were arrested. }\end{array}$ \\
\hline & 06/25th & $1 g$ & $\begin{array}{l}\text { Military police, IBAMA and FUNAI have arrested three } \\
\text { individuals in possession of mercury used in mining } \\
\text { activity carried out in "Novo River", in the Yanomami } \\
\text { Indigenous Land. }\end{array}$ \\
\hline & 09/19th & $290 \mathrm{~g}$ & $\begin{array}{l}\text { Brazilian army. One individual working in mining activity } \\
\text { was arrested during patrol carried out in Uraricoera River, } \\
\text { Waikas community, Yanomami Indigenous Land. }\end{array}$ \\
\hline & $09 / 21$ st & $\begin{array}{l}\text { 1 PET bottle } \\
*\end{array}$ & $\begin{array}{l}\text { Brazilian army. Four individuals working in mining activity } \\
\text { were arrested during patrol carried out in Uraricoera } \\
\text { River, Waikas community, Yanomami Indigenous Land. }\end{array}$ \\
\hline
\end{tabular}




\begin{tabular}{|l|l|l|l|}
\hline 2015 & 05/07th & $\begin{array}{l}1 \text { small bot- } \\
\text { tle } *\end{array}$ & $\begin{array}{l}\text { Federal Police action in in Boqueirão indigenous com- } \\
\text { munity, in compliance with Search and Seizure Warrant. } \\
\text { Warari Koxi operation. One individual was arrested. }\end{array}$ \\
\hline 2016 & - & No seizures & No record of seizures. \\
\hline 2017 & - & No seizures & No record of seizures. \\
\hline
\end{tabular}

Source: Federal Police - February 7th, 2019.

Case studies about two processes referring to the seizure of large amounts of mercury in 2013 were carried out. Based on process n. 0001595-88.2014.4.01.4200, which was in progress at the 1st Federal Court in Boa Vista County (RR), the seizure of 36 kilograms of mercury recorded by the National Mining Agency in 2016 had actually happened on 07/24th/2013. It resulted from the action taken by the Federal Highway Police, which approached a truck driven by one of the individuals reported in the process, who, in his turn, was charged with the crime of smuggling goods such as clothes, medicines, edibles and a cylinder with 36 kilograms of mercury from the Cooperative Republic of Guyana.

The Federal Police inquiry into this fact - which started after the Federal Highway Police reported it to the Federal Police on 07/24th/2013 - was concluded on 09/24th/2013. However, the judicial process remained in progress in March 2020, due to appeal against the Court's decision to sentence the defendants to serve time under open regime. The appeal did not yet get a definitive response from the Court and the process has been in progress for more than six years.

With respect to the seizure of $500 \mathrm{~g}$ of mercury by the Military Police of Roraima State on 05/06th/2013, three individuals were arrested for being caught in possession of mercury while exploiting gold in Couto Magalhães River, in Yanomami Indigenous Land. The sentence was issued by the 2 nd Federal Court in Roraima on 05/30th/2015, under process n. 2805-14.2013.4.01.4200. One of the individuals was acquitted, whereas the other two were sentenced to serve a little more than one year in open regime-none of the convicted individuals was imprisoned. Similar to the previous case, the appeal against the Courts' decision did not yet receive a definitive response from the State-Judge and remains pending decision by the Regional Federal Court of the 1st Region, since 05/03rd/2016.

According to prospectors' testimonies, one part of mercury was used for the amalgamation of one to three parts of gold; the mercury was reused and later discarded in the environment. This process is called "gold cleaning" by mining operators; it consists in the amalgamation and subsequent mercury evaporation-based gold separation from other minerals that do not have economic value -0.5 to $1 \mathrm{~kg}$ of mercury is used per barge operating in Uraricoera River, on a monthly basis.

The Brazilian Federal Police has seized 8.9 kilos of illegally-extracted gold at Boa Vista City Airport (capital of Roraima State) on March 29th, 2018. The transporter, who was arrested in the act, tried to board an aircraft bound for Brasília/DF in possession of gold bars that did not have any document capable of attesting their legal origin (G1 RR, 
2018). Another transporter in possession of 11 kilograms of undocumented and illegal gold was arrested by the Federal Police at Brasília City Airport, as soon as he disembarked from a flight coming from Boa Vista City (RR), on April 16th, 2018 (VERDÉLIO, 2018; ANDREOLLA, 2018). Together, the two aforementioned gold seizures had market value higher than $\mathrm{R} \$ 34$ million.

These seizures comprised part of the gold mined in indigenous lands, which can be easily transported, concealed and illegally inserted in the legal market; its illegal origin is concealed through false documents attesting that the gold was extracted from licensed gold mines and it is traded in other parts of the country where this activity is authorized by the State.

Based on a trip report by the National Indian Foundation (FUNAI), which monitored illicit activities in the Yanomami Indigenous Land, 55 barges used for gold mining were working in Uraricoera River on December 16th, 2016 (FUNDAÇÃO NACIONAL DO INDIO, 2016). Such a fact would require using 27 to 55 kilograms of mercury on a monthly basis, throughout the period investigated by FUNAI.

Based on the report on "Velocino (Fleece) Operation" - which took place in Uraricoera River, Yanomami Indigenous Land, in April 2016 -, IBAMA has caught and deactivated " 20 mining barges, 17 at the first operation day and three at the second day" and "four onshore mining sites", as well as destroyed their mining equipment (INSTITUTO BRASILEIRO DO MEIO AMBIENTE E DOS RECURSOS NATURAIS, 2016). All this activity would require the use of 12 to 24 kilograms of mercury on a monthly basis, throughout the period investigated by IBAMA.

These state actions have ratified the discrepancy among seized gold (final product), equipment observed or destroyed by state agencies and the significantly small amount of mercury seized by the Brazilian state in the exposed records. This finding highlights the poor performance of the State from 2013 to 2017, as pointed out by Campos (2011). Mercury is a highly-polluting chemical product capable of harming human health; it is described by prospectors as essential to the mining activity and intensely used in gold extraction processes taking place in the Yanomami Indigenous Land due to State's leniency.

\section{Different Effects of Mercury and Accountabilities}

Gold extracted from indigenous lands is a non-renewable natural resource (RIVAS, 2014) that "cannot be conserved unless it is not used and, in this case, it would no longer be a resource"(WEID, 2009, p. 35).

Gold exploitation can lead to irreversible damage to the environment (CASTILHOS et al., 2006; RIVAS, 2014). Studies have reported direct impacts of such an activity on the health of Yanomami Indians due to the use of metallic mercury in mining sites (CASTRO; ALBERT; PFEIFFER, 1991; SING et al., 2003; FIOCRUZ, 2016), as well as risks of contamination by fish, which composes Amerindians' protein diet (FRÉRY et al., 2001). Mercury concentrations at health-risk levels were recorded in other Amazonian indigenous populations living in areas close to mining sites (BARBOSA; GARCIA; DE 


\section{SOUZA, 1997; DÓREA et al., 2005).}

Studies focused on comparing mercury levels between individuals living close to, and distant from, mining sites have found increased health-related risk levels in populations living close to gold mining sites (GIBB; O’LEARY, 2014; OLIVEIRO- VERBEL; CABALLERO-GALLARDO; NEGRETE-MARRUGO, 2011). The elevation of mercury vapor at levels thirty times higher than those accepted in gold exploitation sites is also seen as impact, since it represents carcinogenic risk (PAVILONIS et al., 2016).Another impact is the increasing deforestation of forest areas near gold exploitation sites (ASNER et al., 2013), which worsens waterbodies' contamination with mercury released from exposed and, consequently, eroded soils (GUIMARÃES et al., 2000).

Illegal gold extraction activity leads to severe social and environmental damage, as well as significantly harms indigenous communities living in the Amazon region (RODRIGUES, 2017, p. 118). According to the Yanomami people, "smoke deriving from machines and engines is dangerous for those who live in the forest. It is also a metal smoke, an epidemic smoke. We had never smelled such a thing before white people arrived here" (KOPENAWA; ALBERT, 2015, p. 310).

Based on the Yanomami perspective, gold and other ores should remain underground, where they were left by God Omama to sustain the world. Thus, they believe that gold extraction releases the epidemic smoke called Xawara, which will kill all the Yanomami, as well as the non-indigenous peoples, because Europe and the forest are part of the same world sustained by metals embedded underground. Mercury makes the water sick, as well as makes fish flesh soft and rotten. Those who eat these fish are at risk of dying from dysentery, skinny, with strong stomach pain and dizziness (KOPENAWA; ALBERT, 2015).

Another Yanomami indigenous leader I.X. has stated on April 26th, 2013, during his testimony in one of the herein analyzed processes, that he was "very concerned about this dirty water, because it is causing many health issues in the indigenous communities living in the region". Pollution in the water consumed by the Yanomami people was foreseen by Davi Kopenawa, who warned that "we will all die with dry lips" (KOPENAWA; ALBERT, 2015, p. 336), and it was already confirmed by laboratory analyses conducted in Federal University of Roraima (LIMA; BETHONICO; VITAL, 2018). According to statements by Yanomami individuals at the meeting held in the same Amazonian university: seeing "children in the indigenous community bathing in the water and leaving only mud is very worrisome".

The toxic effects of mercury became well known after serious accidents such as the one in Minamata Bay (TAKEUCHI; ETO, 1977). Recent studies have found high mercury levels in indigenous populations worldwide (BARBOSA; DÓREA, 1998; DÓREA et al., 2005; ACHOUBA, 2016); however, they had a hard time in associating individuals' clinical symptoms with contamination levels recorded in the regions they lived in. On the other hand, several indirect negative effects can be associated with human health issues, mainly the ones linked to disruptions in lifestyle (WHEATLEY B; WEATLEY MA, 2000) associated with indigenous cultures. 
Indigenous people's perception about fish contamination can lead to changes in their dietary pattern, such as replacing protein sources with carbohydrate food items, which are lesser nutritious and associated with lesser active and more sedentary life (WHEALEY B; WHEATLEY MA, 2000). Significant changes in lifestyle and in eating patterns among traditional populations worldwide have increased the incidence of cardiovascular diseases (SHAMLAYE et al., 1995) and alcohol consumption (GUTTORMSON, 1995). This outcome highlights the importance of adopting a holistic approach to better understand physical and social factors capable of affecting the health and quality of life of indigenous peoples.

A meeting comprising public bodies such as the National Indian Foundation; NonGovernmental Organizations such as Hutukara and the Socio-Environmental Institute; and Yanomami leaders was held in Boa Vista County (Roraima State) on November 16th, 2017, when Yanomami representatives from regions such as Cachoeira, Palimiú, Catrimani, Uaicás, Maturacá, Homoxi-Xitei and Paapiú reported criminal activities taking place in the Yanomami Indigenous Territory. They described those involved in the illegal activities and requested the implementation of urgent and efficient state measures to protect their land by preventing and suppressing illegal mining activities in the Yanomami Indigenous Territory. Yanomami leaders have questioned the reason why written laws were not enforced.

Yanomami representatives requested the destruction of equipment, pathways and barges, the effective punishment of those involved in the mining process, as well as the implementation of tourism as economic substitute for the participation of some indigenous individuals in gold mining activities. They warned that prospectors "do not have a single penny", but they are financed by gold vendors and third parties interested in profiting from the illicit activity that "spoils the land and the rivers, kills the fish, poisons the water of rivers (...), as well as kills forest and indians".

Brazilian law defines polluter as the one who causes environmental degradation; it holds this individual accountable for indemnifying the ones affected by damages resulting from such degradation (BRASIL, 1981). Legal accountability consists in holding "the one who causes damage to a given third party accountable for bearing the costs deriving from such harm, in a proportion way to the suffering or damage imposed on said third party" (ANTUNES, 2016, p. 555). Once the environmental damage is confirmed, "civil liability arises as the obligation of the person who caused such a damage to make amends" (MELO, 2017, p. 372), as well as administrative and criminal liability, which can result in the offender's arrest (BRASIL, 1988; MELO, 2017; ANTUNES, 2016).

The Brazilian State is responsible for preventing and suppressing illegal mining activities and the use of mercury in indigenous lands in order to protect the environment, indigenous populations and gold itself (as heritage of national interest). These criminal, civil and administrative responsibilities are addressed in Articles 176, 225 and 231 of the 1998 Federal Constitution (BRASIL, 1988). In addition, the legal system is open to international conventions and treaties (PIOVESAN, 2011) focused on reinforcing these responsibilities. 
Article 1 of the International Covenant on Civil and Political Rights (international human rights standard, which has supralegal status in Brazil, within the scope of the global human rights system) states that "all peoples have the right to self-determination" (BRASIL, 1992b). This standard can be interpreted along with ILO Convention n. 169, which is also an international human rights standard with supralegal status, according to which "peoples" can be interpreted as indigenous peoples "totally or partially ruled by their own customs or traditions, or by specific legislation" (BRASIL, 2004).

Based on commitment terms signed by the Brazilian Government, Mercury "causes global concern due to its long-distance atmospheric propagation, persistence in the environment after being anthropogenically introduced in it, ability to bioaccumulate in ecosystems and significantly negative effects on human health and on the environment" (BRASIL, 2018).

The Minamata Convention on Mercury was approved by the Brazilian National Congress in July 2017 - through Legislative Decree n. 99 - and promulgated by the Brazilian President - through Decree n. 9,470, from August 14th, 2018 - in order to "protect human health and the environment from anthropogenic emission and release of mercury and mercury compounds". This international standard also aims at protecting the vulnerability of "indigenous communities due to mercury biomagnification and contamination of traditional food, as well as at protecting these communities from the effects of mercury in a broader way" (BRASIL, 2018).

Article 7 of the aforementioned Convention regulates "artisanal and small-scale gold mining" (idem) and forces the participating States to "adopt measures to reduce and, whenever feasible, eliminate the use of mercury and mercury compounds in these activities, as well as mercury emissions and release resulting from these activities into the environment" (idem). In case of relevant mining activity, an action plan must be developed according to the model addressed in the Convention in order to reverse the harmful effects of it. As for the specific protection of indigenous peoples, the Convention also determines the

development and implementation of strategies and programs to identify and protect populations at risk, mainly the vulnerable ones, which may include the adoption of scientifically-based health guidelines about individuals' exposure to mercury and mercury compounds, as well as the establishment of goals to reduce this exposure (idem).

States participating in the Convention committed themselves to implement "measures to enable the formalization or regulation of the artisanal and small-scale gold mining sector" (idem). With respect to the Yanomami Indigenous Land, it is worth emphasizing that this device must be interpreted along with articles 49, XVI; 176, 231 of the 1988 Federal Constitution (BRASIL, 1988), which determines that the Federal Government must protect and assure respect for indigenous peoples' "social organization, customs, languages, beliefs and traditions, and their original rights to the lands they traditionally live in" (idem). In addition, it holds the National Congress accountable for authorizing 
mineral wealth-mining activity of national interest, as well as the need of free, prior and informed expression of indigenous peoples as binding requirement for the eventual regulation of mining activity in their territory, based on Article 6 of the ILO Convention n.169 of the International Labor Organization (BRASIL, 2004).

In addition to legal accountability, the State and the entire Brazilian society have ethical responsibility towards the Yanomami indigenous community. There was "mismatch between traditional concepts about responsibility and specific conditions concerning biosphere preservation" because "the environment is not an abstract scientific concept; it is an idea closely linked to human life and health" (CRETELLA NETO, 2012, p. 769).

Legal accountability for financial compensation for any losses suffered by individuals - in the legal polluter-payer principle inherent to article 4, VII of Law n. 6.938 / 1981 (BRAZIL, 1981) - is not useful for indigenous communities that have their own customs and are not subjected to the dominant culture. According to the Yanomami people, "money do not protect, feed or make us happy" (KOPENAWA; ALBERT, 2015, p. 217). Arresting the offenders or destroying their equipment does not have effects on the indigenous people, since these individuals and their equipment can be replaced; however, the damage caused by illegal mining and mercury use affects their very existence and sustainability as traditional people, as well as the existence and sustainability of their earth-forest or "urihi" (idem, p. 116). If the mining activity based on mercury use persists, Yanomami's health - herein understood as full physical, mental and social state of well-being (WHO, 1967 ) - will deteriorate. Rupture in indigenous communities' world perspective can have major impact on their health and well-being (WHEATLEY, 1997) and lead to the end of the Yanomami world.

The ethical responsibility dimension (JONAS, 2006) applied to the herein investigated phenomenon enables analyzing the new post-Kantian imperative in the sense that the State and society must act "in a way that the effects of their actions are compatible to the permanence of authentic human life on Earth" in order to protect the indigenous peoples and the Yanomami world (idem, p. 47). Mercury use and illegal mining activity are slowly annihilating the Yanomami people and their forest-land, due to the action of non-indigenous people who "are always too concerned with momentary things" (idem, p. 64). Science corroborates these issues. The State and non-indigenous people, whether through law or ethics, are responsible for the future of the Yanomami people, since there is an explicit and ethical legal duty in our social contract that does not listen to the indigenous voices of the forest on behalf of mining profits (CARRARA, 2016).

It is necessary taking into consideration the ethical responsibility dimension at the time to state that "environmental protection has, in essence, preventive nature, even due to obstacles to return to the status quo" (MELO, 2017, p. 371). In addition, criminal and administrative accountabilities demand State agents to take proactive actions to prevent environmental damage (SOUZA; LINS, 1989; SOUZA; HARTMANN; SILVEIRA, 2015), as well as environmental catastrophes with severe social impacts (BERTOLDI; FREITAS, 2015). The current study has observed that damages caused by mining activities affect the sustainability of different peoples living in the Yanomami Indigenous Land. 
Such a fact reinforces the need of having the State taking preventive actions to undermine the use of mercury and illegal mining activity in the Amazon region.

\section{Final Considerations}

There is a big gap between regulatory protection and fact when it comes to the use of mercury in the Yanomami Indigenous Land. The herein addressed legal standards, which hold the Brazilian State accountable for protecting indigenous populations, their lands and the environment, are strongly in favor of human rights and effective in protecting the culture, heritage and the environment in indigenous lands in order to protect their lives and to enable a balanced environment.

However, the herein investigated phenomenon has evidenced the constant action of prospectors and the need of handling large amounts of mercury along the Amazon rivers to enable gold extraction activity. It has also evidenced State's omission in the small number of times mercury used in mining activities taking place in the Yanomami Indigenous Land was seized, as well as in lack of definitive response from the State-Justice regarding sentences applied to lawbreakers in the analyzed cases.

The accountability of gold prospectors, gold financiers and the State is not restricted to non-compliance with standards and sanctions such as imprisonment or the payment of indemnities to indigenous people. The use of mercury in mining sites has significant impact on vulnerable populations and on their surrounding environment, a fact that corroborates the Yanomami wisdom, as well as the ethical and scientific literature. In addition, such a use can severely harm human health and the environment, as well as lead to the end of the Yanomami world, thus making it impossible for future indigenous generations to enjoy life. The non-indigenous society and the State have the ethical responsibility to preserve future Yanomami generations.

Although indigenous communities living close to mineral exploration zones are the ones mostly affected by the effects of mercury, the damaging effects of such a use are not limited to the Yanomami people and to the Amazon. The isolation conditions of illegal artisanal mining sites make the implementation of criminal and highly-polluting activities easier. The economic, social and environmental cost imposed to the whole society by gold extraction activities is extremely higher than that faced by gold prospectors and investors. The cost to the Yanomami people is hidden by the cultural difference, distance, isolation and ethnocentrism of a dominant society and of a State that does not protect minorities but brings them to extinction due to unsustainable mining activities taking place in their lands.

Environmental and social impacts of gold mining on indigenous lands are immeasurable, since this illegal activity is carried out without enough state control. Thus, it is necessary listening to the affected indigenous peoples, whose claims are reinforced by scientific and ethical literature, in order to help better understanding and acknowledging the indigenous wisdom, as well as to comply with indigenous-protection standards to avoid eliminating individuals who do not participate in this social contract that has 
always excluded them.

The current study has confirmed the hypothesis - previously mentioned in the scientific and anthropological literature and in the Yanomami world perspective - about the intense use of mercury and the extremely harmful consequences of illegal gold mining taking place in the Yanomami Indigenous Territory, Brazilian Amazon region. In addition, the Brazilian State did not take enough action to prevent and suppress the use of mercury in illegal gold mining activities. There was also discrepancy between the protection of human rights of indigenous minorities and the environment in the Brazilian legal framework and the illegal practices analyzed in the current research, a fact that violates indigenous rights, constitutional commandments and international standards the Brazilian Government is subjected to.

\section{References}

ACHOUBA, A. Plasma levels of selenium-containing proteins in Inuit adults from Nunavik. Environment International, [S.1.], v. 96, p. 8-15, nov. 2016.

ANDREOLLA, A. P. G1. Homem é preso com R \$ 1,6 milhão em ouro no aeroporto de Brasília; peças foram pintadas para disfarçar. G1, São Paulo, 17 abr. 2018. Distrito Federal. Disponível em: https://g1.globo.com/df/distrito-federal/noticia/pf-prende-homem-com-11-quilos-de-ouro-em-mala-no-aeroporto-de-brasilia.ghtml. Acesso em: 23 mar. 2020.

ANTUNES, P. de B. Direito ambiental. 18. ed. São Paulo: Atlas, 2016.

ASNER, G. P.; LLACTAYO, W.; TUPAYACHI, R.; LUNA, E. R. Elevated rates of gold mining in the Amazon revealed through high-resolution monitoring. Proceedings of the National Academy of Sciences of the United States of America, [S.1.], v. 110, n. 46, p. 18454-18459, nov. 2013.

BARBOSA, A. C. et al. Mercury contamination in the Brazilian Amazon. Environmental and occupational aspects. Water Air \& Soil Pollution, [S.1.], v. 80, n.1-4, p. 109-121, fev. 1995.

BARBOSA A. C.; DÓREA. J. G. Indices of mercury contamination during breast feeding in the Amazon Basin. Environmental Toxicology and Pharmacology, [S.1.], v. 6, n. 2, p. 71-79, oct. 1998.

BARBOSA, A. C.; GARCIA, A. M.; DE SOUZA, J. R. Mercury contamination in hair of riverine populations of Apiacás. Reserve in the Brazilian Amazon. Water Air \& Soil Pollution, [S.1.], v. 97, n. 1-2, p.1-8, jun. 1997.

BERZAS NEVADO, J. J. et al. Mercury in the Tapajos River basin. Environment International, [S.l.], v. 36, n. 6, p. 593-608, aug. 2010.

BERTOLDI, M. R.; FREITAS, A. C. P. O Princípio da proporcionalidade e a Solução de Conflitos envolvendo o Direito Penal Ambiental Simbólico e do Risco. Veredas do Direito, Belo 
Horizonte, [S.1.], v. 12, n. 24, p. 319-341, jul./dez. 2015.

BRABO, E. S. et al. Níveis de mercúrio em peixes consumidos pela comunidade indígena de Sai Cinza na Reserva Munduruku, Município de Jacareacanga, Estado do Pará, Brasil. Cadernos de Saúde Pública, Rio de Janeiro, v. 15, n. 2, p. 325-331, abr.jun. 1999.

BRASIL. Lei no 6.938, de 31 de agosto de 1981. Dispõe sobre a Política Nacional do Meio Ambiente, seus fins e mecanismos de formulação e aplicação, e dá outras providências. Diário Oficial da União, Brasília, DF, 02 set. 1981. p. 16509.

BRASIL. Decreto no 97.634, de 10 de abril de 1989. Dispõe sobre o controle da produção e da comercialização de substância que comporta risco para a vida, a qualidade de vida e o meio ambiente, e dá outras providências. Diário Oficial da União, Brasília, 12 abr. 1989. Seção 1, p. 5518.

BRASIL. Constituição (1988). Constituição da República Federativa do Brasil. Brasília, DF: Senado Federal, 1988.

BRASIL. Decreto de 25 de maio de 1992. Homologa a demarcação administrativa da Terra Indígena Yanomami, nos Estados de Roraima e Amazonas. Diário Oficial da República Federativa do Brasil, Brasília, 26 mai. 1992a. Seção 1, p. 6457.

BRASIL. Decreto no 678, de 6 de novembro de 1992. Promulga a Convenção Americana sobre Direitos Humanos (Pacto de São José da Costa Rica). Diário Oficial da União, Brasília, 9 nov. 1992b. Seção 1, p. 15562.

BRASIL. Decreto no 5.051, de 19 de abril de 2004. Promulga a Convenção n. 169 da Organização Internacional do Trabalho - OIT sobre Povos Indígenas e Tribais. Diário Oficial da União, Brasília, 20 abr. 2004. Seção 1, p. 1.

BRASIL. Departamento Nacional de Produção Mineral. Anuário Mineral Brasileiro: Principais Substâncias Metálicas. Brasília: DNPM, 2017a. Disponível em: < http://www.anm.gov.br/dnpm/ publicacoes/serie-estatisticas-e-economia-mineral/anuario-mineral/anuario-mineral-brasileiro/ amb_metalicos2017>. Acesso em: 23 de março de 2020.

BRASIL. Lei no 13.575 , de 26 de dezembro de 2017b. Cria a Agência Nacional de Mineração (ANM); extingue o Departamento Nacional de Produção Mineral (DNPM). Diário Oficial da União, Brasília, DF, 27 dez. 2017b. p. 1.

BRASIL. Decreto no 9.470, de 14 de agosto de 2018. Promulga a Convenção de Minamata sobre Mercúrio. Diário Oficial da União, Brasília, 15 ago. 2018. Seção 1, p. 65.

CAMPOS, C. Diversidade socioambiental de Roraima: subsídios para debater o futuro sustentável da região. 2. ed. São Paulo: Instituto Socioambiental, 2011.

CARRARA, O. V. Ética, Meio Ambiente e Mineração. Revista Internacional Interdisciplinar INTERthesis, Florianópolis, v. 13, n. 3, p. 121-142, set./dez. 2016.

CASTILHOS, C. Z. et al. Mercury contamination in fish from gold mining areas in Indonesia 
and human health risk assessment. Science of the Total Environment, [S.1.], v. 368, n. 1, p. 320-325, sep. 2006.

CASTRO, M.B.; ALBERT, B.; PFEIFFER, W.C. Mercury levels in Yanomami Indians hair from Roraima-Brazil. In: INTERNATIONAL CONFERENCE ON HEAVY METALS IN THE ENVIRONMENT, 1., 1991, Edinburg. Heavy Metals in the Environment: international conference. Edinburg: CEP Consultants, 1991. p. 367-370.

CRETELlA NETO, J. Curso de Direito Internacional do Meio Ambiente. São Paulo: Saraiva, 2012.

DÓREA, J. G. et al. Fish consumption (Hair Mercury) and nutritional status of Amazonian Amer-Indian Children. American Journal of Human Biology, [S.1.], v. 17, n. 4, p. 507-514, jun. 2005.

FEIGELSON, B. Curso de Direito Minerário. 2. ed. São Paulo: Saraiva, 2012.

FIOCRUZ. Fundação Oswaldo Cruz. Avaliação da exposição ambiental ao mercúrio proveniente da atividade garimpeira de ouro na terra indígena Yanomami, Roraima, Amazônia, Brasil. Rio de Janeiro: FIOCRUZ, 2016. Disponível em: https://www.socioambiental.org/sites/ blog.socioambiental.org/files/diagnostico_contaminacao_mercurio_terra_indigena_yanomami. pdf. Acesso em: 23 de março de 2020.

FOLHA WEB. Liderança denuncia presença superior a 5 mil garimpeiros na terra indígena Yanomami. Folha BV, Boa Vista, 09 abr. 2018. Polícia. Disponível em: https:/folhabv.com.br/noticia/ Lideranca-denuncia-presenca-superior--a-5-mil-garimpeiros-na-terra-yanomami/38575. Acesso em: 23 de março de 2020.

FRÉRY, N. et al. Gold-Mining Activities and Mercury Contamination of native amerindiam communities in French Guiana: Key Role of Fish in Dietary Uptake. Environmental Health Perspectives, Durham, v. 109, n. 5, p. 449-456, may. 2001.

FUNDAÇÃO NACIONAL DO ÍNDIO - FUNAI. Relatório de viagem executada. Sobrevoo de monitoramento a ilícitos etnoambientais na Terra Indígena Yanomami. Lei de Acesso à Informação - protocolo 08850003328201735, 16 de dezembro de 2016.

G1 RR. PF apreende barras de ouro avaliadas em R\$ 1,3 milhão em aeroporto de Boa Vista. G1, São Paulo, 29 mar. 2018. Roraima. Disponível em: https:/g1.globo.com/rr/roraima/noticia/pf-apreende-barras-de-ouro-avaliadas-em-r-13-milhao-em-aeroporto-de-boa-vista.ghtml. Acesso em: 23 de março de 2020.

GIBB, H.; O'LEARY, K. G. Mercury Exposure and Health Impacts among Individuals in the Artisanal and Small-Scale Gold Mining Community: A Comprehensive Review. Environmental Health Perspectives, Durham, v. 122, n. 7, p. 667-672, jul. 2014.

GOLDPRICE: Gold price per gram. Birmingham. 2019. Disponível em: < https://www.gold. co.uk/gold-price/gold-price-per-gram/> . Acesso em: 23 de março de 2020. 
GUIMARÃES, J. R. D. et al. Mercury net methylation in five tropical flood plain regions of Brazil: High in the root zone of floating macrophyte mats but low in surface sediments and flooded soils. Science of Total Environment, [S.1.], v. 261, n. 1-3, p. 99-107, oct. 2000.

GUTTORMSON, K. White dog fights use of thinner by natives. TimesColonist Victoria, 26 may. 1995. Section A, p. 17.

INSTITUTO BRASILEIRO DO MEIO AMBIENTE E DOS RECURSOS NATURAIS RENOVÁVEIS - IBAMA Memorando no 352/2017/COFIS/CGFIS/DIPRO. Resposta ao pedido de informação n 6893/2017, encaminhada pelo Sr. Alan Robson Alexandrino Ramos, 2018.

JONAS, H. O Princípio responsabilidade. Ensaio de uma ética para a civilização tecnológica. Rio de Janeiro: Contraponto Editora, PUC, 2006.

KOPENAWA, D.; ALBERT, B. A queda do céu: palavras de um xamã yanomami. São Paulo: Companhia das Letras, 2015.

LARINI, L. Toxicologia. 3. ed. São Paulo: Editora Manole, 1997.

LIMA, J. A. M.; BETHONICO, M. B. M.; VITAL, Marcos J. S. Água e Doenças Relacionadas à Água em Comunidades da Bacia Hidrográfica do Rio Uraricoera - Terra Indígena Yanomami Roraima. Hygeia. [S.1.], v. 14, n. 27, p. 136-154, mar. 2018.

MACHADO, P. A. L. Direito Ambiental Brasileiro. 24. ed. São Paulo: Malheiros, 2016.

MAHAFFEY, K. R. Fish and shellfish as dietary sources of methylmercury and the omega-3 fatty acids, docosahexaenoic acid and docosahexaenoic acid: risks and benefits. Environmental Research, [S.1.], v. 95, n. 3, p. 414-28, jul. 2004.

MELO, F. Direito Ambiental. 2. ed. Rio de Janeiro: Forense, 2017.

MERCADO LIVRE. Osasco, 2018. Disponível em: < http://www.mercadolivre.com.br >. Acesso em: 24 set. 2018.

MILARÉ, E. Direito do ambiente. 3. ed. São Paulo: Editora Revista dos Tribunais, 2004.

MINAMATA CONVENTION ON MERCURY. Vernier: United Nations Programme, 2018. Disponível em: < http://www.mercuryconvention.org/Countries/Parties/tabid/3428/language/en-US/Default.aspx.> Acesso em: 23 de março de 2020.

OLIVEIRO-VERBEL, J.; CABALLERO-GALLARDO, K. NEGRETE-MARRUGO, J. Relationship Between Localization of Gold Mining Areas and Hair Mercury Levels in People from Bolivar, North of Colombia. Biological Trace Element Research, [S.l.], v. 144, n. 1, p. 118-132, dec. 2011.

OLX. Rio de Janeiro, 2018. Disponível em: <http://www.olx.com.br>. Acesso em: 24 set. 2018.

ONU. Declaração das Nações Unidas sobre os Direitos dos Povos Indígenas. Rio de Janeiro: 
UNIC, 2008.

PAVILONIS, B. et al. Characterization and risk of exposure to elements from artisanal gold mining operations in the Bolivian Andes. Environmental Research, New York, v. 154, n. 1, p. 1-9, apr. 2016.

PIOVESAN, Flávia. Direitos Humanos e o Direito Constitucional Internacional. 12. ed. São Paulo: Saraiva. 2011.

PRESS, Frank. et al. Para entender a terra. 6. ed. Porto Alegre: Bookman, 2013.

RAMOS, A.; RODRIGUES, F. dos S. O Garimpo Ilícito na Terra Indígena Yanomami entre a Cosmovisão Indígena e Ações Estatais. Unisul de Fato e de Direito: revista jurídica da Universidade do Sul de Santa Catarina, [S.1.], v. 9, n. 16, p. 25-35, mai. 2018.

RIVAS, A. Economia e valoração de serviços ambientais utilizando técnicas de preferências declaradas. Manaus: Editora da Universidade Federal do Amazonas, 2014.

RODRIGUES, F. dos S. Garimpagem e mineração no norte do Brasil. Manaus: Editora da Universidade Federal do Amazonas, 2017.

SHAMLAYE, C. F. et al. The Seychelles child development study on neurodevelopmental outcomes in children following in utero exposure to methylmercury from a maternal fish diet: background and demographics. Neurotoxicology, [S.1.], v. 16, n. 4, p. 597-612, 1995.

SING, K.A. et al. Organic Mercury levels among the Yanomami of the Brazilian Amazon Basin. Ambio: A Journal of the Human Environment, [S.1.], v. 32, n. 7, p. 434-439, nov. 2003.

SOUZA, L. da R.; HARTMANN, D.; SILVEIRA, T. A. Dano Ambiental e a Necessidade de uma Atuação Proativa da Administração Pública. Veredas do Direito. Belo Horizonte, v. 12, n. 24. p. 343-373, Jul./dez. 2015.

SOUZA, V. P. de; LINS, F. A. F. Recuperação do ouro por amalgamação e cianetação: problemas ambientais e possíveis alternativas. Rio de Janeiro: CETEM/CNPq, 1989.

TAKEUCHI, T.; ETO, K. Pathology and pathogenesis of Minamata disease. In: TSUBAKI, T.; IRUKAYAMA, K. (ed.). Minamata Disease: Methylmercury Poisoning in Minamata and Niigata, Japan. Tokyo: Kodansha 1977. p. 103-141.

VEGA, C. M. et al. Human Mercury Exposure in Yanomami Indigenous Villages from the Brazilian Amazon. International Journal of Environmental Research and Public Health, [S.1.], v. 15, n. 6, p. 1-13, may. 2018.

WANDERLEY, L. J. Geografia do Ouro na Amazônia brasileira: uma análise a partir da porção meridional. 2015.. Tese (Doutorado em ciências) -Programa de Pós-graduação em Geografia, Universidade Federal do Rio de Janeiro, Rio de Janeiro, 2015.

WASSERMAN, J. C.; HACON, S.; WASSERMAN, M. A. Biogeochemistry of mercury in the 
Amazonian environment. Ambio: A Journal of the Human Environment, [S. 1.], v. 32, n. 5, p. 336-342, aug. 2003.

WEID, J. M. V. Articulação entre os diferentes componentes da sustentabilidade agrícola. Revista Raízes, Campina Grande, v. 28, n. 1-2, p. 34-40, jan./dez. 2009.

WHEATLEY, B.; WHEATLEY, M. A. Methylmercury and the health of indigenous peoples: a risk management challenge for physical and social sciences and for public health policy. The Science of the Total Environment, v. 259, n. 1-3, p. 23-29, oct. 2000.

WHEATLEY, M. A. Social and cultural impacts of mercury pollution on Aboriginal peoples in Canada. Water Air \& Soil Pollution, [S. 1], v. 97, n. 1-2, p. 85-90, jun. 1997.

WHO. The Constitution of the World Health Organisation.WHO Chronicles 1, Geneva, 1967.

WHO. World Health Organization. Guidance for Identifying Populations at Risk from Mercury Exposure. Geneva: UNEP Chemicals, 2008. Disponível em: < https://www.who.int/foodsafety/publications/chem/mercuryexposure.pdf?ua=1>. Acesso em: 23 de março de 2020.

VERDÉLIO, A. Polícia Federal apreende R \$ 1,3 milhão em barras de ouro em Roraima. Agência Brasil EBC, Brasília, 30 mar. 2018. Disponível em: http://agenciabrasil.ebc.com.br/geral/noticia/2018-03/policia-federal-apreende-r-13-milhao-em-barras-de-ouro-em-roraima. Acesso em: 23 de março de 2020.

VIVEIROS DE CASTRO, E. de. Metafísicas canibais: Elementos para uma antropologia pós- estrutural. São Paulo: Cosac Naify, 2015. 
Alan Robson Alexandrino Ramos

ఐalanrobsonce@yahoo.com.br

ORCiD: https://orcid.org/0000-0001-9878-7494
Submitted on: 09/01/2018

Accepted on: 26/05/2020

2020;23:e03262

\section{Keyty Almeida de Oliveira}

$\square$ keytyaoliveira@gmail.com

ORCiD: https://orcid.org/0000-0002-1996-0023

\section{Francilene dos Santos Rodrigues}

$\square$ france.rodrigues@ufrr.br

ORCiD: https://orcid.org/0000-0003-1618-3684

How to cite: RAMOS, A. R. A.; OLIVEIRA, K. A. de. Mercury-Based Mining in Yanomami Indigenous Lands and Accountabilities. Ambiente $\&$ Sociedade. São Paulo, v. 23, p. 1-22, 2020. 


\title{
Mercúrio nos Garimpos da Terra Indígena Yanomami e Responsabilidades
}

\author{
Alan Robson Alexandrino Ramos \\ Keyty Almeida de Oliveira \\ Francilene dos Santos Rodrigues
}

São Paulo. Vol. 23, 2020

Artigo Original
Resumo: A exploração de ouro em terras indígenas na Amazônia, com uso de mercúrio, é clandestina e causa impactos socioambientais. Os Yanomami próximos aos garimpos do rio Uraricoera estão expostos à contaminação pelo mercúrio, metal com propriedades de bioacumulação. Objetiva-se análise de caráter interdisciplinar do uso do mercúrio nos garimpos da Terra Indígena Yanomami, em Roraima, bem como avaliar as respostas dos órgãos de Estado ao fenômeno. A partir do levantamento bibliográfico e documental de abordagem qualitativa, envolvendo a voz indígena Yanomami e procedimentos policiais, administrativos e processos judiciais de 2013 a 2017, percebeu-se intenso uso de mercúrio e danos da atividade ilícita, com insuficiente ação estatal. Há divergências entre a proteção e responsabilidades inscritas na ordem jurídica brasileira e o fenômeno clandestino estudado, em violação às vozes indígenas, científicas e a imperativo ético, que coadunam na possibilidade de prejuízos e no fim do mundo e do povo Yanomami.

Palavras-chave: Garimpo; Mercúrio; Meio Ambiente; Terras Indígenas.

Como citar: RAMOS, A. R. A.; OLIVEIRA, K. A. de. Mercúrio nos Garimpos da Terra Indígena Yanomami e Responsabilidades. Ambiente \& Sociedade. São Paulo, v. 23, p. 1-22, 2020.

DOI: http://dx.doi.org/10.1590/1809-4422asoc20180326r2vu2020L5AO 


\title{
Mercurio en la Minería de las Tierras Indígenas Yanomami y Responsabilidades
}

\author{
Alan Robson Alexandrino Ramos \\ Keyty Almeida de Oliveira \\ Francilene dos Santos Rodrigues
}

São Paulo. Vol. 23, 2020

Artículo original
Resumen: La explotación de oro en tierras indígenas en la Amazonia utilizando mercurio, es clandestina y causa impactos socioambientales. Los yanomami cerca de las minas del río Uraricoera están expuestos a la contaminación por mercurio, un metal con propiedades de bioacumulación. Se objetiva análisis de carácter interdisciplinario del uso del mercurio en las garimpos de la Tierra Indígena Yanomami, en Roraima, así como evaluar las respuestas de los órganos de Estado al fenómeno. A partir del levantamiento bibliográfico y documental de un enfoque cualitativo, involucrando la voz Yanomami y procedimientos policiales, administrativos y procesos judiciales de 2013 a 2017, se percibió intenso uso de mercurio y daños de la actividad ilícita, con insuficiente acción estatal. Hay divergencias entre la protección y responsabilidades inscritas en el orden jurídico brasileño y el fenómeno clandestino estudiado, en violación a las voces indígenas, científicas y el imperativo ético, que pueden llevar al fin del mundo y del pueblo Yanomami.

Palabras-clave: Garimpo; Mercurio; Medio Ambiente; Tierras Indígenas.

Como citar: RAMOS, A. R. A.; OLIVEIRA, K. A. de. Mercurio en la Minería de las Tierras Indígenas Yanomami y Responsabilidades. Ambiente $\&$ Sociedade. São Paulo, v. 23, p. 1-22, 2020.

DOI: http://dx.doi.org/10.1590/1809-4422asoc20180326r2vu2020L5AO 